\title{
The Relationship between Bank EFFICIENCY AND RISK AND Productivity PatTeRns IN THE ROMANIAN BANKING SYSTEM
}

\author{
Mihai NIȚOI ${ }^{1}$ \\ Cristi SPUĹBĂR ${ }^{2}$
}

\begin{abstract}
Using a data envelopment model and an input slack-based productivity index, we investigate commercial banks' cost efficiency and productivity patterns in the Romanian banking system over the period of 2005 to 2011. In a second stage, we assess the determinants of efficiency, emphasizing the relation between efficiency and risks. In the Romanian banking system, the relationship between concentration and efficiency supports Hicks's 'quiet life hypothesis'. With respect to the impact risk factors on efficiency, we find that a lower failure risk and a higher liquidity are positively associated with efficiency, while solvency risk is negatively associated with efficiency. We also find that banks with a higher return on equity and a higher level of financial intermediation are more efficient. An increase in the net interest margin leads to a decrease in efficiency, signaling a higher credit risk. The effects of the financial crisis on commercial banks in Romania were observable in 2008, when the cost efficiency and productivity decreased. Empirical results suggest that the contribution of the funds to the increase in productivity is the most significant, while that of labor and capital productivity is lower.
\end{abstract}

Keywords: bank efficiency, risk-taking, productivity, performance, DEA JEL Classification: C30, G21

\section{Introduction}

The banking system has a major influence on the economic development of a country. Moreover, within an emerging economy, the efficient functioning of the banking system in allocating resources leads to higher economic growth (Caporale et al. 2009, Bonin and Watchel, 2003). In Romania, over the last years the banking system is the most important part of the financial system, holding more than $75 \%$ of its financial assets

\footnotetext{
${ }^{1}$ Institute of World Economy, Romanian Academy. E-mail: mihai.nitoi@iem.ro.

2 Department of Finance, University of Craiova. Corresponding author. E-mail: cristi.spulbar@feaa.ucv.ro.
} 
(National Bank of Romania, 2014). Given these conditions, the efficiency and productivity of the Romanian banking system are two elements without which the economy cannot grow in a sustainable and robust manner.

In the last two decades, the banking system in Romania has evolved in a similar manner to the ones in the other Eastern and Central European countries. To be more precise, the shift from a centralized economy to a market economy involved the reorganization of the banking system on two levels, and also the reform of the legislative framework, liberalization and privatization. Furthermore, at the end of the $20^{\text {th }}$ century, the banking system in Romania had to face a crisis characterized by bank failures and by severe deterioration of the performance of other banks. Getting rid of non-viable banks and also marking the end of the reform process, at the beginning of 2000s we witnessed the entrance of the banking system in a new development period.

This was followed by a period in which the banking system benefited from regained economic growth. Until 2008, the banks in Romania had been extending their loan portfolios in conditions of increased profitability. An important particularity of the banking system in Romania is that more than $90 \%$ of the financial assets are owned by foreign banks or banks controlled by foreign shareholders (National Bank of Romania, 2014). Moreover, the Romanian banking system was significantly financed by foreign funds. For example, according to the National Bank of Romania (2013), between 2007 and 2011 the banking system exposure to external debt accounted for more than $25 \%$ of the balance sheet. Thus, the banking system in Romania, as well as other banking systems in Central and Eastern Europe, became vulnerable in the face of sudden slowdown of the external loans that occurred in the autumn of 2008 (Montoro and Rojas-Suarez, 2012; Klingen 2013). Also, the banking system in Romania was affected after 2008 by a considerable increase in the nonperforming loans. Thus, if in 2008 the percentage of nonperforming loans was 2.75\%; in 2013 it had reached 21.75\% (National Bank of Romania, 2013). The high percentage of nonperforming loans reflects weak credit standards adopted by the credit institutions in a period of economic growth, and also the existence of various unsustainable domestic booms. In our opinion, in Romania the global financial crisis has substantially modified the way the banks operate. Therefore, the evaluation of efficiency, productivity and risks became the most important component of banks' strategy.

Regarding organization, the Romanian banking system is a universal one, dominated by commercial banks. Moreover, for the credit institutions in Romania there are no aspects that particularize their form of organization, the structure of shareholders or the nature of the ongoing activities. Most of the credit institutions are organized as banks, despite the fact that the law allows the establishment of specialized credit institutions. It is worth mentioning that the banking system in Romania encompasses two building societies, as well as one central credit cooperative, which include 46 credit cooperatives. Nevertheless, the market percentage of the building societies and credit cooperatives is below $1 \%$.

Having in view the major importance of the banking system within the financial system and that of the commercial banks within the banking system, and also the risks the banks have faced in the context of the financial crisis, this study aims at emphasizing the nexus between banks' efficiency and the risks they have undertaken. Moreover, we have also highlighted the relation between banks' efficiency, concentration and 
The Relationship between Bank Efficiency and Risk and Productivity Patterns

performance. Banks' cost efficiency and its determinants are evaluated in two stages. Firstly, we obtain the efficiency scores through the data envelopment analysis. Secondly, through several models, we evaluate the determinants of banks' efficiency. A second objective of the study is to emphasize the patterns of banks' productivity, and also its sources. To this aim, we use an advanced productivity index that allows the breakdown of productivity in accordance with the contribution of each input (Chang et al., 2012). The contribution of our study to the bank efficiency literature is manifold. Firstly, to our knowledge, the relationship between cost efficiency and risk in the Romanian banking system is not covered in the literature. Secondly, in order to capture the determinants of bank cost efficiency we used several models, which provided reliability to our results. Thirdly, to estimate the productivity patterns we used an index which allowed us to calculate how each input factor influenced productivity.

The rest of the paper is organized as follows: Section II reviews the literature on efficiency studies, paying special attention to the Romanian commercial banks. Section III presents the methodology framework adopted in this study. Section IV describes the data and variables. Section V displays the empirical results. Finally, Section VI presents the conclusions.

\section{Literature Review}

In the economic literature, there are various studies that use stochastic frontier analysis (SFA) or data envelopment analysis (DEA) to estimate bank efficiency, and the Malmquist index or the Luenberger index to estimate productivity growth. Hereinafter, we present those studies that investigated bank efficiency determinants and productivity growth in the transition countries and which included the Romanian banking system in the sample.

A significant number of studies focused on cross-country research. Most of these studies aimed at identifying the relationship between efficiency and ownership, but were also focused on the factors that influenced efficiency. Koutsomanoli-Filippaki et al. (2009) studied bank efficiency and productivity change in Central and Eastern Europe over the period 1998-2003. The findings revealed strong links of competition and concentration with bank efficiency. Also, productivity declined in the whole region. With respect to the Romanian banking system, the results showed that the banks in Romania were among the least efficient and exhibited a clear downward trend in productivity. Fries and Taci (2005) investigated cost efficiency in the Eastern European banking systems. They showed that the association between a country's progress in banking reform and cost efficiency was non-linear. With regard to the Romanian banking system, the findings revealed lower efficiency in comparison with other countries included in the sample. Andrieş and Cocriş (2010) analyzed bank efficiency in Romania, the Czech Republic and Hungary over the period 2000-2006. They also found that the Romanian banks were among the least efficient. The authors showed that asset quality, bank size, inflation rate, reform, liberalization and ownership were the main factors that influenced the efficiency level in these countries. Spulbăr and Nițoi (2014) studied the determinants of bank efficiency in the transition economies over the period 2005-2011. The findings revealed that banks with a more cautious strategy, characterized by lower risk appetite and average expectations on profitability, had higher cost efficiency. Also, it was 
revealed that traditional deposit-taking and loan-making still remained the most efficient activities of the banks. Country cost efficiency revealed that the effects of the financial crisis were less significant in South Eastern Asia in comparison with Latin America and Central and Eastern Europe. Also, the Romanian banks have the lowest cost efficiency level in Central and Eastern Europe. Pancurova and Lyocsa (2013) analyzed the determinants of bank efficiency for 11 Central and Eastern European countries over the period 2005-2008. Their results showed that bank size and financial capitalization were positively associated with cost and revenue efficiency, while loans-to-assets ratio was negatively associated with cost efficiency, but positively associated with revenue efficiency. However, a lot of studies emphasize the ownership effect on bank efficiency in the transition economies. In general, most of the results indicated a positive effect of foreign ownership and privatization on bank efficiency (Koutsomanoli-Filippaki et al., 2009; Bonin et al., 2005; Fries and Taci, 2005; Yildirim and Philippatos, 2007; Fang et al., 2011; Havranek and Irsova, 2013).

In the literature there are also studies that analysed only the Romanian banking system. Asaftei and Kumbhakar (2008) estimated the impact of the regulation implemented by the central bank in Romania over the bank cost efficiency in the period 1996-2002. The findings showed that the cost of technical inefficiency decreases in the years following the tightening of regulations. Nițoi (2009) examined the efficiency and productivity of Romanian banks over the period 2006-2008. The results indicated low cost efficiency scores and that the foreign banks and larger banks had higher efficiency than the domestic banks and smaller banks, respectively. Andrieş et al. (2013) investigated the efficiency and productivity of Romanian banks over the period 2004 to 2008 . They results showed that the private banks were more efficient and had a higher productivity in comparison with the public banks. The study examined the determinants of bank efficiency. The findings revealed that ROA and total assets positively influenced overall efficiency, while net interest margin negatively influenced bank efficiency. Munteanu et al. (2013) analyzed the productivity of Romanian banks over the period 2006-2011. Their findings indicated that scale efficiency and management efficiency influenced the productivity growth and that foreign banks outperformed the domestic banks.

\section{Methodology}

In order to estimate the efficiency scores and their determinants, we use a two-stage analysis. Therefore, in the first stage we estimate the efficiency scores using DEA, while in the second stage we assess the efficiency determinants.

As we have mentioned earlier, most of the studies use either SFA or DEA to estimate the bank efficiency. In comparison with a parametric approach, a non-parametric DEA does not require a particular functional form for the frontier. Therefore, in the case of a parametric approach, a misspecification of the production frontier may lead to overstating inefficiency. On the other hand, DEA does not allow for the presence of a random error term. As a result, any deviation from the efficiency frontier is associated with inefficiency. The productivity patterns are computed using an index that disaggregates total factor productivity growth into each input productivity change (Chang et al., 2012). 
The Relationship between Bank Efficiency and Risk and Productivity Patterns

Charnes et al. (1978) proposed a model based on the allocation of the inputs and outputs for each decision making unit (DMU). The efficiency is measured using linear programming. Coelli (1996) computed the dual solution of DEA using duality as follows:

$$
\begin{gathered}
\min \theta_{k} \\
\text { subject to } \\
-y_{i k}+\sum_{n=1}^{N} \lambda_{n} y_{i n} \geq 0, \\
\theta x_{j k}-\sum_{n=1}^{N} \lambda_{n} x_{j n} \geq 0, \\
\lambda_{n} \geq 0
\end{gathered}
$$

where: $\theta$ represents the technical efficiency of the $i$ th $\mathrm{DMU}$ and $\lambda$ is a constant. In our study, we use the input prices. Therefore, the cost minimization DEA model becomes:

$$
\begin{gathered}
\operatorname{minw}_{j k}^{\prime} x_{j k}^{*} \\
\text { subject to } \\
-y_{i k}+\sum_{n=1}^{N} \lambda_{n} y_{i n} \geq 0, \\
x_{j k}^{*}-\sum_{n=1}^{N} \lambda_{n} x_{j n} \geq 0, \\
\lambda_{n} \geq 0
\end{gathered}
$$

where: $w_{j k}^{\prime}$ and $x_{j k}^{*}$ are the input prices and cost minimizing input quantities, respectively, for the $k$ th DMU.

After we obtained the efficiency scores for each bank, we apply different models to find the main determinants of bank efficiency. Therefore, we use a censored regression model, more exactly the Tobit model, with censoring efficiency scores equal to one (Model 1). The Tobit model can be expressed as follows:

$$
\begin{array}{cc}
y_{i}=x_{i} \beta+e_{i} \text { if } x_{i} \beta+e_{i}<1 \\
=1 & \text { otherwise }
\end{array}
$$

where: $y_{i}$ is the cost efficiency score, $x_{i}$ is a vector that includes the explanatory variables, $\beta$ represents the estimated parameters and $e_{i}$ is the error term distributed.

However, Simar and Wilson (2007) criticize the use of a Tobit model on the grounds of the potential bias in efficiency estimates, having in view the serial correlation problem, and suggest the use of a truncated regression. Also, McDonald (2009) argues that the efficiency scores are not censored but are fractional. Consequently, we apply Simar and Wilson (2007) model (Model 2) and the fractional logit model (Model 3) proposed by Papke and Wooldridge (1996), to obtain more robust results. 
To measure productivity, we used the input slack-based productivity index (ISP) proposed by Chang et al. (2012). The productivity index is computed using inputoriented directional distance functions and a Färe-Lovell efficiency measure, as follows:

$$
I S P_{i}=\frac{1}{2}\left[\left(\vec{D}_{i(t)}\left(x^{t}, y^{t}\right)-\vec{D}_{i(t)}\left(x^{t+1}, y^{t+1}\right)\right)+\left(\vec{D}_{i(t+1)}\left(x^{t}, y^{t}\right)-\vec{D}_{i(t+1)}\left(x^{t+1}, y^{t+1}\right)\right)\right]
$$

In order to compute the input-oriented directional distance functions, Chang et al. (2012) used a Färe-Lovell efficiency measure, introduced by Briec (2000). Using linear programming, the distance functions for observation $o$ in time $t$ is calculated as follows:

$$
\begin{gathered}
\vec{D}_{t}\left(x^{t}, y^{t}\right)=\max \frac{1}{M}\left(\beta_{1}+\cdots+\beta_{M}\right) \\
\text { s.t. } \sum_{j=1}^{N} \lambda_{j} x_{i j}^{t} \leq x_{i o}^{t}\left(1-\beta_{i}\right), \\
\sum_{j=1}^{N} \lambda_{j} y_{r j}^{t} \geq y_{r o}^{t}, \\
\lambda_{j} \geq 0, \beta_{i} \geq 0, \\
j=1, \ldots, N ; i=1, \ldots, M ; r=1, \ldots, S .
\end{gathered}
$$

where: $M$ are the inputs; $S$ the outputs for each $N$ objects in each time period of $t ; \lambda_{j}$ is an $n \times 1$ vector and $\beta_{i}$ is a scalar that indicates indicates the proportional contraction of the $i$ th input in order to catch up the efficient frontier. The $i$ th input and $r$ th output variable of the $j$ th object are represented by $x_{i j}^{t}$ and $y_{r j}^{t}$ in time $t$, respectively. The efficiency measure introduced by Briec (2000) has the advantage of selecting a strong efficient vector onto the frontier, and it is based on the CRS assumption.

Chang et al. (2012) decomposed the total factor productivity change into the productivity change in individual inputs using the following formula:

$$
\begin{aligned}
T F P C H=E F F C H & + \text { TECHCH } \\
& =\frac{1}{M}\left[E_{F F C H}+\cdots+\text { EFFCH }_{M}\right]+\frac{1}{M}\left[\text { TECHCH }_{1}+\cdots+\text { TECHCH }_{M}\right] \\
& =\frac{1}{M}\left[I S P_{1}+\cdots+I S P_{M}\right]
\end{aligned}
$$

where: $T F P C H$ is the total factor productivity change, $E F F C H$ is the efficiency change and $T E C H C H$ is the technological change. The main advantage of the ISP index is that allows us to calculate how each input factor influences productivity.

\section{Data}

Most of the studies use either the intermediation approach, which considers banks to be financial intermediaries that buy inputs in order to generate earning assets, or the production approach that treats banks as producers of financial services. Having in view the fact that the intermediation approach is closer to the main function of the bank as a financial intermediary (Sealey and Lindley, 1977), in our study we use the first approach. 
The Relationship between Bank Efficiency and Risk and Productivity Patterns

The output vector includes total loans and other earning assets. In order to ensure comparable quality, we subtracted loan loss provisions from total loans (Havrylchyk, 2006). The input vector includes funds (total deposits and short term funding), physical capital (total fixed assets) and labor (number of employees). The input prices are price of funds, price of capital and price of labor. The price of funds is measured by dividing total interest expenses by total deposits and other short term funding. The price of capital is defined by the ratio of other noninterest expenses to total fixed assets. The price of labor is calculated as personnel expenses divided by number of bank employees. All monetary values were deflated by using the Gross Domestic Product (GDP) deflator provided by the International Monetary Fund, with 2005 as the base year. To estimate productivity we used the output and the input vector. The input prices were used, alongside output and input vector, to estimate cost efficiency.

Our sample covers a balanced panel dataset of 98 observations corresponding to 14 commercial banks in Romania over the period 2005 to 2011. The data were extracted from the Bankscope database. We should mention that the 14 commercial banks have a market share of over $60 \%$ in the banking system. Table 1 presents the summary statistics of the output and input variables.

Table 1

Descriptive Statistics

\begin{tabular}{lllll}
\hline & Mean & SD & Min. & Max. \\
\hline Output quantities (in billion US \$) & & & & \\
Total loans & 2.1199 & 3.1390 & 0.0650 & 13.6 \\
$\begin{array}{l}\text { Other earning assets } \\
\text { Input quantities }\end{array}$ & 0.4622 & 0.6410 & 0.0026 & 3.1845 \\
$\begin{array}{l}\text { Deposits and short term funding (in } \\
\text { billion US \$) }\end{array}$ & & & & \\
Fixed Assets (in billion US \$) & 2.8268 & 4.1353 & 0.1001 & 19.2 \\
$\quad$ Number of employees & 0.0952 & 0.1448 & 0.0028 & 0.6090 \\
Input prices & 2809.735 & 3221.213 & 123 & 13486 \\
Price of funds & & & & \\
Price of labor & 0.0483 & 0.0164 & 0.02 & 0.1 \\
Price of capital & 20.3976 & 6.1145 & 9.13 & 41.97 \\
\hline
\end{tabular}

Among the explanatory variables, we included the bank concentration index, the $Z$ score, equity to total assets ratio, liquidity ratio, return on equity $(\mathrm{ROE})$, net interest margin, loans to customer deposits ratio.

The bank concentration index is a proxy of competition in the banking industry. Bank concentration index was extracted from the World Bank Statistics Database. The relation between concentration and efficiency has been widely studied in the bank efficiency literature (Bikker and Haaf, 2002; Kasman and Yildirim, 2006; Yildirim and Philippatos (2007); Koutsomanoli-Filippaki et al., 2009, Hauner, 2005). On one hand, higher concentration in the banking industry could lead to higher efficiency, if concentration is the result of superior management and greater efficiency in the production process (Demsetz, 1969). Also, Dick and Lehnert (2010) pointed that a more concentrated and competitive market lowers bank credit risk and increases lending 
efficiency. On the other hand, higher concentration could lead to a decline in bank efficiency, if concentration is associated with market power.

The $Z$ score, equity to total assets ratio and liquidity ratio are included in the analysis in order to capture the banks' risk taking. The $Z$ score is a measure of failure risk. Lepetit et al. (2008a) used the $Z$ score to measure the probability of bankruptcy for a bank. A higher $Z$ score reflects a lower probability of failure. Hence, the $Z$ score should have a positive impact on bank cost efficiency. The $Z$ score is computed on the basis of the following formula:

$$
Z=\frac{R O A+E Q / T A}{S D R O A}
$$

where: $R O A$ is return on assets ratio; $E Q / T A$ is the equity to total assets ratio and $S D R O A$ is the standard deviation of the $R O A$.

Equity to total assets ratio is a measure of solvency risk. Its effect on efficiency is rather vague. On one hand, banks with higher ratio benefit from lower borrowing costs, which make them be perceived as more reliable, but they can also ignore potentially profitable investment opportunities. On the other hand, a lower ratio can indicate capital adequacy problems (Heffernan and Fu, 2010). Liquid assets to deposits and short term funding are a measure of liquidity risk. A higher ratio indicates a lower liquidity risk, and reflects a banks' ability to respond to loan demands. Also, banks with high liquidity can cope easily with possible unexpected deposit withdrawals or liquidity crises occurring on the interbank market. The influence that liquidity risk has on inefficiency should be negative. ROE, net interest margin and loans to customer deposits ratio are included among the explanatory variables in order to measure banks' performance. ROE and the net interest margin are measures of bank profitability. Basically, banks with a high profitability rate should be more efficient. Moreover, the two rates are commonly used in the literature to describe the performance of banks (De Haas and van Lelyveld, 2006; Otchere, 2005; $\mathrm{Xu}, 2011)$.The net interest margin could be also a measure for credit risk. Maudos and de Guevara (2004) and Lepetit et al. (2008b) showed that banks tend to increase the interest margins if credit risk increase. Fries and Taci (2005) consider that loans to customer deposits ratio is a measure of the efficiency of the financial intermediation process. Thus, a very low ratio could indicate banks' incapacity to transform deposits into loans. Other authors see this ratio as a measure of the liquidity risk, higher values indicating an increased liquidity risk for banks (Williams and Nguyen, 2005). Basically, a higher ratio should have a positive impact on efficiency.

\section{Results}

The cost efficiency scores, as well as technical efficiency and allocative efficiency are presented in Table 2. We should have in mind that efficiency is measured on a scale of 0 to 1 , where a value of 1 indicates efficiency, and a value lower than 1 indicates inefficiency. The analysis of cost efficiency discloses important findings. Our results show that the cost efficiency has increased significantly in 2006. Interestingly, in 2007 we find that the banks' cost efficiency has decreased. However, 2008 brought a major decrease in efficiency, its level reaching the lowest value for the analyzed period. In our opinion, this result may reflect the effects of the global financial crisis, which has 
The Relationship between Bank Efficiency and Risk and Productivity Patterns

significantly affected the banking system. Interestingly, banks' speed of reaction was quite remarkably. They have managed to rapidly increase the efficiency and, as a consequence, the cost efficiency index increased in 2009, 2010 and 2011.

Table 2

Cost Efficiency: Decomposition into Technical and Allocative Efficiency

\begin{tabular}{cccc}
\hline & Technical efficiency & Allocative efficiency & Cost efficiency \\
\hline 2005 & 0.911 & 0.680 & 0.626 \\
2006 & 0.914 & 0.914 & 0.750 \\
2007 & 0.848 & 0.841 & 0.719 \\
2008 & 0.782 & 0.762 & 0.589 \\
2009 & 0.883 & 0.867 & 0.764 \\
2010 & 0.906 & 0.886 & 0.804 \\
2011 & 0.883 & 0.912 & 0.812 \\
\hline
\end{tabular}

As mentioned earlier, an important objective of the paper is to emphasize the determinants of cost efficiency and, especially, the nexus between efficiency and risks. Also, among the efficiency determinants we introduced, in addition to the risk factors, indicators that characterize concentration in the banking system and banks' performance. As one may see, the results for the three models are quite similar, indicating consistent and solid results. The results obtained are presented in Table 3.

Table 3

Cost Efficiency Determinants

\begin{tabular}{|c|c|c|c|}
\hline & Model 1 & Model 2 & Model 3 \\
\hline \multicolumn{4}{|l|}{$\begin{array}{l}\text { Dependent variable } \\
\text { Cost efficiency }\end{array}$} \\
\hline \multicolumn{4}{|l|}{ Independent variables } \\
\hline Bank concentration & $-0.0110^{*}$ & $0.0111^{*}$ & $-0.0630^{*}$ \\
\hline Z score & $0.0295^{\star \star *}$ & $-0.0308^{\star *}$ & $0.1148^{* * *}$ \\
\hline Equity to total assets ratio & $-0.0235^{\star}$ & $0.0224^{*}$ & $-0.1116^{* *}$ \\
\hline $\begin{array}{l}\text { Liquid assets to deposits and short term } \\
\text { funding }\end{array}$ & $0.0025^{\star \star \star}$ & $-0.0023^{\star * *}$ & $0.0190^{* *}$ \\
\hline ROE & $0.0009^{* * *}$ & -0.0002 & 0.0034 \\
\hline Net interest margin & $-0.0457^{\star}$ & $0.0194^{* *}$ & $-0.1843^{*}$ \\
\hline Loans to customer deposits ratio & $0.0022^{*}$ & $-0.0030^{*}$ & $0.0204^{*}$ \\
\hline Constant & $1.5884^{*}$ & $0.6930^{\star * *}$ & $4.7587^{*}$ \\
\hline Log-likelihood & 7.1810 & 54.7391 & \\
\hline Sample size & 80 & 80 & 98 \\
\hline
\end{tabular}

Notes: In the case of Model (1) and Model (2), 18 observations are censored and, respectively, truncated. For Model (1) and Model (3) efficiency is measured on a scale of 0 to 1 , where a value of 1 indicates efficiency, and a value less than 1 indicates inefficiency. For Model (2) efficiency is measured on a scale of 1 to 2 , where a value of 1 indicates efficiency, and a value higher than 1 indicates inefficiency. ${ }^{*},{ }^{* *}$ and ${ }^{* * *}$ denote test statistic significance at the $1 \%, 5 \%$ and $10 \%$ levels, respectively.

Our results suggest that a high level of concentration in the Romanian banking system will lead to the lower cost efficiency level. The result supports Hicks's 'quiet life hypothesis' (QLH). Hicks's QLH assumes that in an uncompetitive market more market power could generate inefficiency. The results in the efficiency literature are mixed. Berger and Hannan (1998), Weill (2004), Hauner (2005) indicated a negative relation 
between concentration and efficiency, while Kasman and Yildirim (2006), Yildirim and Philippatos (2007), Koutsomanoli-Filippaki et al. (2009) obtained a positive relation.

Also, our estimates suggest that the $Z$ score, which measures the risk of failure, has a positive effect on efficiency. As a result, banks with a lower risk appetite and a lower risk of failure are more efficient. Surprisingly, equity to total assets ratio, a measure for solvency risk, has a negative influence on efficiency. Hence, commercial banks with a low solvency risk, namely a higher equity to assets ratio, are more inefficient. This result may reflect either the fact that the Romanian banks ignore potential investment opportunities, or the fact that they do not manage to borrow at a lower costs. Our result is similar to those obtained by Sun and Chang (2011); Hermes and Nhung (2010), while Yildirim and Philippatos (2007), Zajc (2006), Berger and DeYoung (1997), Fries and Taci (2005), Hsiao et al. (2010) obtained a positive relation between efficiency and solvency risk. In line with the expectations, banks with a higher liquidity ratio are more efficient. One possible explanation for this is that the banks which respond more promptly to the loan demands and to the needs of their customers manage their costs more efficiently.

Banks with a higher ROE are more efficient. The obtained outcome is similar to the efficiency literature findings, which indicate the fact that the banks with a higher level of profitability are more efficient (Zajc, 2006; Berger and Mester, 1997; Pastor et al., 1997; Yildirim and Philippatos, 2002; Hermes and Nhung, 2010). However, in the case of Model (2) and Model (3) the coefficient associated with ROE is not significant. Surprisingly, the net interest margin has a negative influence on efficiency. The result can be explained through that fact that a higher interest margin is a sign of higher credit risk. Loans to customer deposits ratio have a positive influence on efficiency. Therefore, the commercial banks with a higher level of financial intermediation are more cost efficient.

The second objective of the paper was to identify the patterns of bank productivity in Romania and the factors which influenced it. The results obtained are presented in Table 4.

The evolution of total factor productivity index (TFP) shows a positive trend over the period 2005 to 2007 . The highest productivity growth for the analyzed period was in 2007 , when the productivity index increased by $20.4 \%$. In 2008 , the level of productivity decreased by $3.8 \%$. In our opinion, this result is caused by the negative impact of the global financial crisis on the banks in Romania. In the period 2009-2011, banks have improved their productivity, significantly in 2009 , and subsequently with lower rates of growth. Important aspects can be drawn from the analysis of the influence of funds, labor and capital on productivity. Thus, in 2006 and 2007 the fund productivity, labor and capital had a positive influence on productivity. In 2008, the TFP index became negative. The results indicate that the productivity growth in 2009 was due to the significant growth of fund productivity; the labor and capital productivity growth being negative. Basically, banks have managed to increase fund productivity by $33 \%$. This result may reflect in fact the focus of banks towards increasing the efficiency of resources. On average, the contribution of fund productivity on the increase in productivity is the most significant, while that of the labor productivity is the least important. 
The Relationship between Bank Efficiency and Risk and Productivity Patterns

Table 4

Annual Productivity Change

\begin{tabular}{lcrrrrr}
\hline & \multicolumn{3}{c}{ Input contribution to TFP growth } & \multicolumn{2}{c}{ TFP decompositions } \\
\hline & $\begin{array}{c}\text { TFP } \\
\text { change }\end{array}$ & \multicolumn{1}{c}{ Fund } & Labor & Capital & $\begin{array}{c}\text { Efficiency } \\
\text { change }\end{array}$ & $\begin{array}{c}\text { Technological } \\
\text { change }\end{array}$ \\
\hline $2005 / 2006$ & 0.0547 & 0.0403 & 0.0905 & 0.0333 & 0.1277 & -0.0730 \\
$2006 / 2007$ & 0.2047 & 0.1603 & 0.2505 & 0.2035 & -0.0217 & 0.2264 \\
$2007 / 2008$ & -0.0384 & -0.0766 & -0.0775 & 0.0387 & -0.0804 & 0.0420 \\
$2008 / 2009$ & 0.1095 & 0.3313 & -0.0026 & -0.0002 & 0.1900 & -0.0805 \\
$2009 / 2010$ & 0.0262 & -0.0163 & 0.0032 & 0.0918 & -0.0014 & 0.0276 \\
$2010 / 2011$ & 0.0088 & 0.0274 & -0.0233 & 0.0224 & -0.0071 & 0.0159 \\
Mean & 0.0609 & 0.0777 & 0.0401 & 0.0649 & 0.0345 & 0.0264 \\
\hline
\end{tabular}

Productivity can be decomposed into efficiency change and technological change. Efficiency change means that banks have moved closer to the efficient frontier. Hence, a positive/negative efficiency change indicates a catching up/falling behind effect. Technological change measures the technological progress/regress. Williams et al. (2011) states that a positive technological change, indicating that the efficient frontier has shifted out as compared to the previous period, results from innovations and the adoption of new technologies by best-practice banks. As we may see from the data presented in Table 4, over the sample period the average growth of TFP has been of $6.09 \%$. Also, the efficiency change has a more significant contribution to the average growth of productivity. In fact, in 2006 and 2009 the results indicated an important growth in efficiency change, due to the efforts of inefficient banks to catch up with the best practice banks. In addition, having in view that efficiency change grew by $19 \%$ in 2009 , but also that funds productivity was higher by $33 \%$ in 2009 , we conclude that banks avoided a regress of productivity through an imitation behavior of fund productivity. To be more precise, the inefficient banks adopted the best practice banks strategies where the management of funds was concerned. With the exception of 2007, the technological growth was relatively modest, which can reflect a lack of innovation among the credit institutions in Romania.

\section{Conclusions}

In this paper, we analyzed the nexus between cost efficiency, risks and performance and productivity patterns in the Romanian banking system during 2005-2011. In our opinion, it is important to know the way in which the efficiency of the banks has evolved and its determinants. To reach this objective, we included in the model variables that characterize the level of bank concentration, the failure risk, the solvency risk, the liquidity risk and the bank's performance. With regard to the productivity patterns, the model we used has allowed us to identify the sources of productivity growth.

The results revealed important conclusions. The influence of the banking concentration on the commercial banks' efficiency support Hicks's 'quiet life hypothesis'. In our opinion, this may result from an uncompetitive banking sector, in which concentration is associated with market power.

The influence of risk factors is mixed. On one hand, the banks characterized by a reduced risk of failure and a higher level of liquidity are more efficient. On the other 
hand, surprisingly, the equity-to-assets ratio, a proxy for solvency risk, has a negative influence on cost efficiency. The data show that the commercial banks in Romania which have a higher rate of financial intermediation and a higher ROE are more efficient. Surprisingly, an increase in the net interest margin will lead to a lower cost efficiency score. In our opinion, this result can indicate a targeting of resources towards riskier assets.

Where productivity is concerned, results indicate a regress in 2008 , caused by the effects of the international financial crisis. Moreover, the cost efficiency decreased significantly in 2008 . These results can indicate a pro-cyclical behavior. Subsequently, in 2009 banks managed to increase the productivity level due to the increase in the productivity of funds. Another element that contributed in a constructive way to a positive level of productivity in 2009 was the fact that the small banks succeeded to get a hold on the catching up effect.

In our opinion, our findings have implications for policy makers and for bank management. Firstly, policy makers should adopt more counter-cyclical measures in order to mitigate bank risk-taking in periods of economic growth. Secondly, bank management should focus more on cost efficiency and productivity. Thirdly, bank management should implement more innovative strategies in order to increase the technological progress.

A future direction of analysis could be a comparative study between the cost efficiency and productivity in Central Eastern Europe. Also, it would be interesting to underline the differences in efficiency and productivity in accordance with the size of banks and their type of ownership. We leave this for future research.

\section{Acknowledgements}

This work was financially supported through the project "Routes of academic excellence in doctoral and post-doctoral research - READ" co-financed through the European Social Fund, by Sectoral Operational Programme Human Resources Development 2007-2013, contract no POSDRU/159/1.5/S/137926."

\section{References}

Andrieş, A.M. and Cocriş, V., 2010. A comparative analysis of the efficiency of Romanian banks. Romanian Journal of Economic Forecasting, 54, pp. 54-75.

Andrieş, A. Mehdian, S. and Stoica, O., 2013. Impact of European integration on efficiency and productivity growth of Romanian banks. Engineering Economics, 24, pp. 187-197.

Asaftei, G. and Kumbhakar, S.C., 2008. Regulation and efficiency in transition: the case of Romanian banks. Journal of Regulatory Economics, 33, pp. 253282.

Berger, A.N. and DeYoung, R., 1997. Problem loans and cost efficiency in commercial banks. Journal of Banking and Finance, 21, pp. 849-870. 
The Relationship between Bank Efficiency and Risk and Productivity Patterns

Berger, A.N. and Hannan, T.H., 1998. The efficiency cost of market power in the banking industry: A test of the "quiet life" and related hypotheses. Review of Economics and Statistics, 80, pp. 454-465.

Berger, A.N. and Mester, L.J., 1997. Inside the black box: What explains differences in the efficiencies of financial institutions?. Journal of Banking and Finance, 21, pp. 895-947.

Bikker, J.A. and Haaf, K., 2002. Competition, concentration and their relationship: An empirical analysis of the banking industry. Journal of Banking and Finance, 26, pp. 2191-2214.

Bonin, J.P. Hasan, I. and Wachtel, P., 2005. Privatization matters: Bank efficiency in transition countries. Journal of Banking and Finance, 29, pp. 21552178.

Bonin, J.P. and Wachtel, P., 2003. Financial sector development in transition economies: Lessons from the first decade. Financial Markets, Institutions \& Instruments, 12, pp. 1-66.

Briec, W., 2000. An extended Färe-Lovell technical efficiency measure. International Journal of Production Economics, 65, pp.191-199.

Caporale, G.M. Rault, C. Sova, R. and Sova, A., 2009. Financial development and economic growth: Evidence from ten new EU members. DIW Berlin Discussion Paper No. 940, Berlin.

Chang, T.P. Hu, J. L. Chou, R.Y. and Sun, L., 2012. The sources of bank productivity growth in China during 2002-2009: A disaggregation view. Journal of Banking and Finance, 36, pp. 1997-2006.

Charnes, A. Cooper, W.W. and Rhodes, E., 1978. Measuring the efficiency of decision making units. European journal of operational research, 2, pp. 429-444.

Coelli, T.J., 1996. A guide to FRONTIER version 4.1: A computer program for stochastic frontier production and cost function estimation. CEPA Working papers.

De Haas, R. and Van Lelyveld, I., 2006. Foreign banks and credit stability in Central and Eastern Europe. A panel data analysis. Journal of banking and Finance, 30, pp. 1927-1952.

Demsetz, H., 1969. Information and efficiency: another viewpoint. Journal of Law and Economics, 12, pp.1-22.

Dick, A.A. and Lehnert, A., 2010. Personal bankruptcy and credit market competition. The Journal of Finance, 65, pp. 655-686.

Fang, Y. Hasan, I. and Marton, K., 2011. Bank efficiency in South-Eastern Europe. Economics of Transition, 19, pp. 495-520.

Fries, S. and Taci, A., 2005. Cost efficiency of banks in transition: Evidence from 289 banks in 15 post-communist countries. Journal of Banking and Finance, 29, pp. 55-81.

Hauner, D., 2005. Explaining efficiency differences among large German and Austrian banks. Applied Economics, 37, pp. 969-980.

Havranek, T. and Irsova, Z., 2013. Determinants of bank performance in transition countries: A Data Envelopment Analysis. Transition Studies Review, 20, pp. 1-17. 
Havrylchyk, O., 2006. Efficiency of the Polish banking industry: foreign versus domestic banks. Journal of Banking and Finance, 30, pp. 1975-1996.

Heffernan, S.A. and Fu, X., 2010. Determinants of financial performance in Chinese banking. Applied Financial Economics, 20, pp. 1585-1600.

Hermes, N. and Nhung, V.T. H., 2010. The impact of financial liberalization on bank efficiency: evidence from Latin America and Asia. Applied Economics, 42, pp. 3351-3365.

Hsiao, H.C., Chang, H., Cianci, A.M. and Huang, L.H., 2010. First financial restructuring and operating efficiency: Evidence from Taiwanese commercial banks. Journal of Banking and Finance, 34, pp. 1461-1471.

Kasman, A. and Yildirim, C., 2006. Cost and profit efficiencies in transition banking: the case of new EU members. Applied Economics, 38, pp. 1079-1090.

Klingen, C., 2013. Perspectives on growth prospects for Central, Eastern and Southeastern Europe. Banking in Central and Eastern Europe and Turkey - Challenges and Opportunities, European Investment Bank, Luxembourg.

Koutsomanoli-Filippaki, A. Margaritis, D. and Staikouras, C., 2009. Efficiency and productivity growth in the banking industry of Central and Eastern Europe. Journal of Banking and Finance, 33, pp. 557-67.

Lepetit, L. Nys, E. Rous, P. and Tarazi, A., 2008a. Bank income structure and risk: An empirical analysis of European banks. Journal of Banking and Finance, 32, pp. $1452-67$.

Lepetit, L. Nys, E. Rous, P. and Tarazi, A., 2008b. The expansion of services in European banking: Implications for loan pricing and interest margins. Journal of Banking and Finance, 32, pp. 2325-35.

Maudos, J. and de Guevara, J. F., 2004. Factors explaining the interest margin in the banking sectors of the European Union. Journal of Banking and Finance, 28, pp. 2259-2281.

McDonald, J., 2009. Using least squares and tobit in second stage DEA efficiency analyses. European Journal of Operational Research, 197, pp. 792798.

Montoro, C. and Rojas-Suarez, L., 2012. Credit at times of stress: Latin American lessons from the global financial crisis. BIS Working Papers No. 370, Bank for International Settlements, Basel.

Munteanu, A., Brezeanu, P. and Badea, L., 2013. Productivity change patterns in the Romanian banking system-the impact of size and ownership on total factor productivity. Theoretical and Applied Economics, 20, pp. 35-52.

Nițoi, M., 2009. Efficiency in the Romanian banking system: An Application of Data Envelopment Analysis. Romanian Journal of Economics, 28, pp. 159173.

National Bank of Romania, 2013. Report on Financial Stability. Available at http://www.bnro.ro/PublicationDocuments.aspx?icid=6711 (Accessed in 2 April 2014). 
The Relationship between Bank Efficiency and Risk and Productivity Patterns

National Bank of Romania, 2014. Report on Financial Stability. Available at http://www.bnro.ro/PublicationDocuments.aspx?icid=6711 (Accessed in 16 December 2014).

Otchere, I., 2005. Do privatized banks in middle-and low-income countries perform better than rival banks? An intra-industry analysis of bank privatization. Journal of Banking and Finance, 29, pp. 2067-2093.

Pancurova, D. and Lyocsa, S., 2013. Determinants of Commercial Banks' Efficiency: Evidence from 11 CEE Countries. Czech Journal of Economics and Finance (Finance a uver), 63, pp.152-179.

Papke, L.E. and Wooldridge, J. M., 1996. Econometric methods for fractional response variables with an application to $401(\mathrm{k})$ plan participation rates. Journal of Applied Econometrics, 11, pp. 619-632.

Pastor, J.T. Lozano, A. and Pastor, J.M., 1997. Efficiency of European banking systems: A correction by environment variables. Instituto Valenciano de Investigaciones Económicas. Working Paper no. 97-12.

Sealey, C. and Lindley, J.T., 1977. Inputs, outputs and a theory of production and cost at depository financial institution. Journal of Finance, 32, pp. 12511266.

Simar, L. and Wilson, P.W., 2007. Estimation and inference in two-stage, semiparametric models of production processes. Journal of econometrics, 136, pp. 31-64.

Spulbăr, C. and Nițoi, M., 2014. Determinants of bank cost efficiency in transition economies: evidence for Latin America, Central and Eastern Europe and South-East Asia. Applied Economics, 46, pp. 1940-1952.

Sun, L. and Chang, T.P., 2011. A comprehensive analysis of the effects of risk measures on bank efficiency: Evidence from emerging Asian countries. Journal of Banking and Finance, 35, pp. 1727-1735.

Weill, L., 2004. On the relationship between competition and efficiency in the EU banking sectors. Kredit und Kapital, 3, pp. 329-352.

Williams, J. and Nguyen, N., 2005. Financial liberalisation, crisis, and restructuring: A comparative study of bank performance and bank governance in South East Asia. Journal of Banking and Finance, 29, pp. 2119-2154.

Williams, J., Peypoch, N. and Barros, C.P., 2011. The Luenberger indicator and productivity growth: a note on the European savings banks sector, Applied Economics, 43, pp. 747-755.

$\mathrm{Xu}, \mathrm{Y} ., 2011$. Towards a more accurate measure of foreign bank entry and its impact on domestic banking performance: The case of China. Journal of Banking and Finance, 35, pp. 886-901.

Yildirim, H.S. and Philippatos, G.C., 2007. Efficiency of banks: recent evidence from the transition economies of Europe, 1993-2000. European Journal of Finance, 13, pp. 123-143.

Zajc, P., 2006. A comparative study of bank efficiency in Central and Eastern Europe: The role of foreign ownership, International Finance Review, 6, pp. 117-156. 